\title{
Identification and First Report of Fusarium andiyazi Causing Sheath Rot of Zizania latifolia in China
}

\author{
Ya-Min Ma ${ }^{1,2,+}$, Jun-Zi Zhu ${ }^{1,+}{ }^{,}$Xiao-Gang Li $^{3, *}$, Lai-Liang Wang ${ }^{4, *}$ and Jie Zhong ${ }^{1, *}$ \\ 1 Hunan Provincial Key Laboratory for Biology and Control of Plant Diseases and Insect Pests, \\ Hunan Agricultural University, Nongda Road 1, Furong District, Changsha 410128, China; \\ mym13957049350@sina.com (Y.-M.M.); zjz0808@gmail.com (J.-Z.Z.) \\ 2 Jinyun Plant Protective Station, Daqiao North Road 290, Lishui 321400, China \\ 3 Hunan Engineering Research Center of Agricultural Pest Early Warning and Control, \\ Hunan Agricultural University, Nongda Road 1, Changsha 410128, China \\ 4 Lishui Institute of Agricultural and Forestry Sciences, Liyang Stress 827, Lishui 323000, China \\ * Correspondence: 1xgang@aliyun.com (X.-G.L.); jywlljn@163.com (L.-L.W.); wzzhtx@sina.com (J.Z.) \\ + Ya-Min Ma and Jun-Zi Zhu contributed equally to this work.
}

Citation: Ma, Y.-M.; Zhu, J.-Z.; Li, X.-G.; Wang, L.-L.; Zhong, J. Identification and First Report of Fusarium andiyazi Causing Sheath Rot of Zizania latifolia in China. Plants 2021, 10, 1844. https://doi.org/ 10.3390/plants10091844

Academic Editors: Roxana Vidican, Erica Lumini and Sotiris Tjamos

Received: 22 June 2021

Accepted: 25 August 2021

Published: 6 September 2021

Publisher's Note: MDPI stays neutral with regard to jurisdictional claims in published maps and institutional affiliations.

Copyright: (C) 2021 by the authors Licensee MDPI, Basel, Switzerland. This article is an open access article distributed under the terms and conditions of the Creative Commons Attribution (CC BY) license (https:/ / creativecommons.org/licenses/by/ $4.0 /)$.

\begin{abstract}
Zizania latifolia is a perennial plant native to East Asia. The swollen culm of Z. latifolia is a popular vegetable and traditional herbal medicine consumed in China and some other Asian countries. From 2019 to 2021, a sheath rot disease was found in Zhejiang Province of China. Symptoms mainly occurred in the leaf sheath showing as brown necrotic lesions surrounded by yellow halos. The pathogen fungal isolates were isolated from the affected sheaths. Ten representative isolates were selected for morphological and molecular identification by phylogenetic analyses of the translation elongation factor 1- $\alpha$ (TEF1) and the RNA polymerase II subunit beta (RPB2) gene regions. Based on the combined datasets, the fungal isolates were identified as Fusarium andiyazi. Koch's postulates were confirmed by pathogenicity test, re-isolation and re-identification of the fungal isolates. To the best of our knowledge, this is the first report of sheath rot caused by F. andiyazi in Z. latifolia in China.
\end{abstract}

Keywords: Fusarium andiyazi; morphological characterization; jiaobai; phylogenetic analysis

\section{Introduction}

Zizania latifolia belongs to the rice tribe (Oryzeae) of the grass family Poaceae [1], also called jiaobai in China, due to its white bamboo [2]. Z. latifolia is a perennial aquatic herbaceous plant. Its terrestrial stem can from 2 to 3 tilers. Due to its unique taste and nutritional and economic importance, Z. latifolia has been domesticated as a vegetable crop for approximately 2000 years and has become a delicacy for people's daily consumption. It is widely cultivated in China, Japan, Korea and countries in Southeast Asia [3]. The Jiangsu and Zhejiang provinces of China have the largest cultivation areas of this plant [4].

A few diseases have been found to be associated with Z. latifolia, thus limiting the production of this plant. Several pathogenic fungi have been found in Z. latifolia, including Bipolaris [5], Claviceps [6], Pyricularia [7] and Pythiogeton [7,8]. However, up to now, no Fusarium spp. has been reported to cause disease in Z. latifolia.

Sheath rot is one of the most severe diseases in crops, and prevalence of the disease can lead to severe crop loss. In the natural state of the field, the disease mainly appears in leaf sheaths and forms irregular, brown, erosive spots, so it is called sheath rot. The spots first were water-stained elliptic or brown dots, and then they expanded. Multiple spots were converged to form black and brown irregular patches, which gradually spread to the lower or upper parts of the leaf sheaths and resulted in the entire sheath to wither and die. Corn Fusarium sheath rot (CFSR) is a serious crop disease in China that has been caused by Fusarium species, such as F. graminearum, F. verticillioides, F. equiseti, F. fujikuroi, F. meridionale and F. asiaticum $[9,10]$. Therefore, according to symptoms and pathogens, we named the disease identified in this study sheath rot. 
According to previous studies, Fusarium spp. are important plant pathogens and can cause many diseases in plants of the grass family Poaceae, such as ear rot, stalk rot, seedling blight and root rot in maize [11,12]. It is difficult to distinguish Fusarium spp. by only morphology because of the variety of species [13]. Therefore, molecular-based techniques were developed and became simple, rapid and efficient methods for identification of fungal species [14]. Fusarium andiyazi has been found in some plants, such as maize [15], sorghum [16] and rice [17,18]. However, it has not been found in Z. latifolia.

The purpose of this study was to isolate and identify the causal pathogen of a novel sheath rot disease of Z. latifolia. Conventional morphological identification, together with DNA sequencing of parts of the translation elongation factor-1a (TEF1) and RNA polymerase II subunit beta (RPB2) genes, was carried out. This research will provide an important basis for effective control strategies for this disease.

\section{Results}

\subsection{Occurrence of Sheath Rot in Zizania latifolia}

From 2019 to 2021, a disease of sheath rot was observed in Z. latifolia in Zhejiang Province of China. Disease symptoms mainly occurred in the leaf sheath showing as watersoaking chlorosis spots on the ear leaf near the sheath in the early stage, then expanded and extended to the lower leaf sheath surrounded by yellow halos, with a diffusion diameter of more than 5 to $10 \mathrm{~cm}$. At a later stage, lesions developed into a brown to black color and had a white mycelium layer faintly visible in the lesions (Figure 1a,b). Among twenty-eight investigated wild fields, the disease incidence ranged from $30 \%$ to $80 \%$, with an average of $56.71 \pm 2.59 \%$.
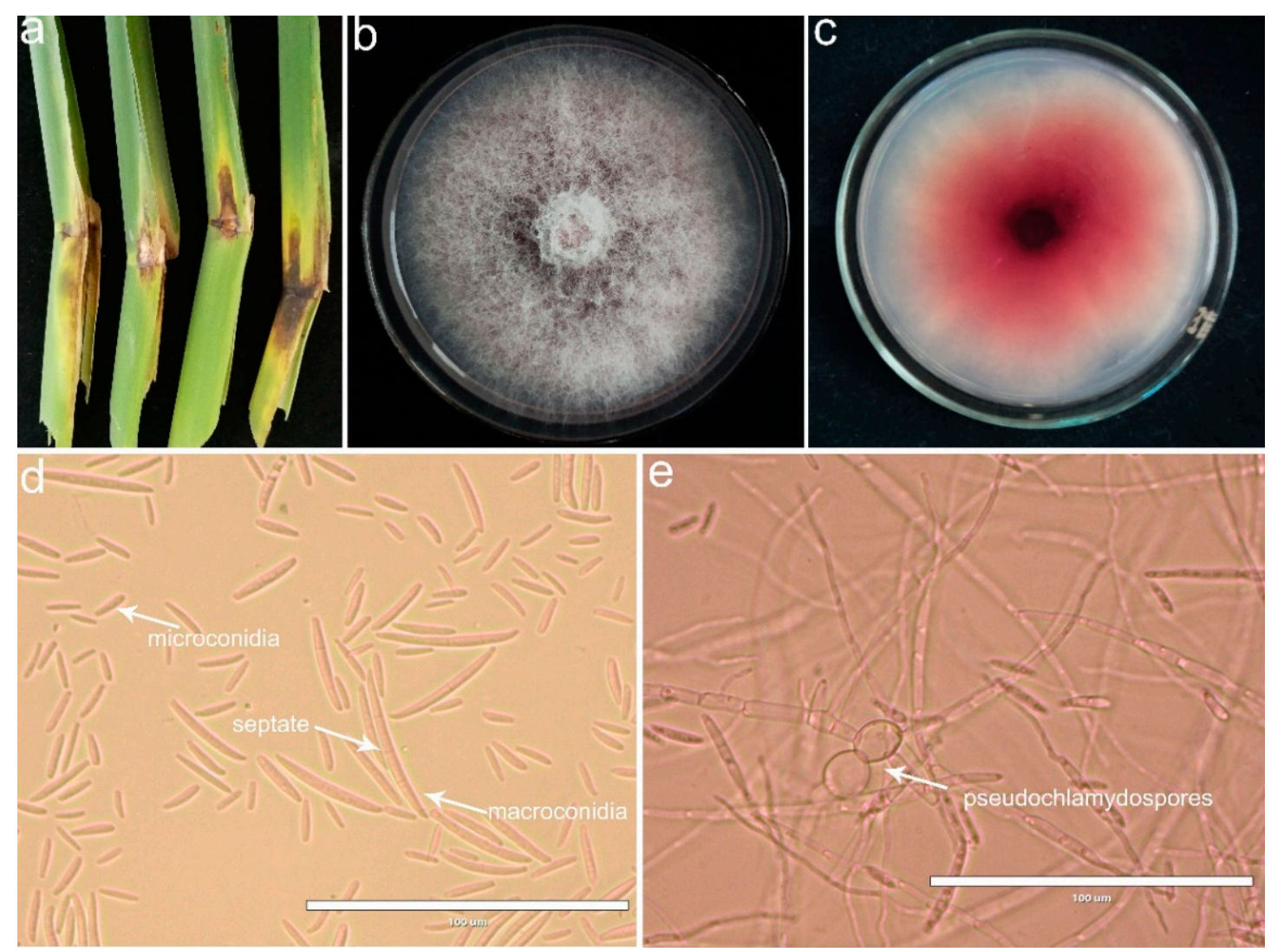

Figure 1. Symptoms of sheath rot observed on Zizania latifolia and morphological and cultural characteristics of colonies and conidia. (a) Sheath rot in field-collected Z. latifolia plants; (b) positive sides of the colonies cultured on potato dextrose agar (PDA) for 6 days; (c) reverse sides on PDA; (d) micrographs of the microconidia and the macroconidia; (e) micrographs of the pseudochlamydospores. Scale bar $=100 \mu \mathrm{m}$. 


\subsection{Fungal Isolation and Morphological Identification}

A total of fifty-eight fungal isolates were obtained from sixty Z. latifolia sheath samples collected from Lishui, Jinhua, Taizhou and Jiaxing of the Zhejiang Province of China. Based on the morphology observation, these fungal isolates were putatively known as Fusarium species. We selected ten isolates for further morphological and molecular identification. When cultured on PDA medium, the fungal isolates were white and gradually varied from tan to pale lilac, exhibiting floccose to powdery mycelium. Fungal isolates produced abundant conidia after 7 days of culture on carnation leaf agar (CLA). Microscopic observations revealed that the macroconidia were straight or slightly curved, had a pedicellate basal cell and slightly curved apical cell, with $3-5$ septate, and measured $30.99-80.95 \times 1.54-4.63 \mathrm{~mm}$. Microconidia were unicellular, oval with a flat base, aseptate, measuring $6.85-24.81 \times 1.17-4.68 \mathrm{~mm}$ in size. Pseudochlamydospores with smooth thinner walls and in solitary or short chains were observed in hyphae. The features of the microconidia and macroconidia are described in Table 1.

Table 1. Micromorphology of the microconidia and macroconidia of ten representative isolates produced on carnation leaf agar medium.

\begin{tabular}{|c|c|c|c|c|c|c|}
\hline \multirow{3}{*}{ Isolate } & \multicolumn{4}{|c|}{ Conidial Size $(\mu \mathrm{m})^{a}$} & \multicolumn{2}{|c|}{ Mean $\pm S^{b}(\mu \mathrm{m})$} \\
\hline & \multicolumn{2}{|c|}{ Microconidia } & \multicolumn{2}{|c|}{ Macroconidia } & \multirow{2}{*}{ Microconidia } & \multirow{2}{*}{ Macroconidia } \\
\hline & Length & Width & Length & Width & & \\
\hline JB-2 & $7.28-24.81^{\mathrm{a}}$ & $1.32-4.30^{\mathrm{a}}$ & $32.48-80.47^{\mathrm{a}}$ & $1.60-4.63^{\mathrm{a}}$ & $14.50 \pm 0.69 \times 2.68 \pm 0.12$ & $44.37 \pm 1.48 \times 3.35 \pm 0.12$ \\
\hline JB-3 & $7.13-24.56^{\mathrm{a}}$ & $1.23-4.02^{\mathrm{a}}$ & $31.95-78.16^{\mathrm{a}}$ & $1.69-4.37^{\mathrm{a}}$ & $14.56 \pm 0.60 \times 2.69 \pm 0.10$ & $43.97 \pm 1.72 \times 3.19 \pm 0.11$ \\
\hline JB-4 & $6.85-25.29^{a}$ & $1.38-4.14^{\mathrm{a}}$ & $31.36-81.35^{\mathrm{a}}$ & $1.54-4.47^{\mathrm{a}}$ & $14.55 \pm 0.61 \times 2.53 \pm 0.09$ & $43.96 \pm 1.69 \times 3.25 \pm 0.10$ \\
\hline JB-5 & $7.43-24.67^{\mathrm{a}}$ & $1.17-4.55^{\mathrm{a}}$ & $31.64-79.51^{a}$ & $1.82-4.55^{\mathrm{a}}$ & $14.74 \pm 0.58 \times 2.7 \pm 0.11$ & $44.31 \pm 1.62 \times 3.03 \pm 0.09$ \\
\hline JB-6 & $7.55-22.92^{a}$ & $1.51-3.91^{\mathrm{a}}$ & $32.55-80.76^{\mathrm{a}}$ & $1.96-4.60^{\mathrm{a}}$ & $14.18 \pm 0.45 \times 2.58 \pm 0.09$ & $44.83 \pm 1.53 \times 3.30 \pm 0.11$ \\
\hline JB-8 & $7.97-23.45^{\mathrm{a}}$ & $1.15-4.60^{\mathrm{a}}$ & $31.82-81.09^{a}$ & $2.02-4.32^{\mathrm{a}}$ & $14.44 \pm 0.62 \times 2.70 \pm 0.13$ & $44.16 \pm 1.74 \times 3.01 \pm 0.10$ \\
\hline JB-11 & $7.21-23.78^{a}$ & $1.37-4.16^{\mathrm{a}}$ & $30.99-80.95^{\text {a }}$ & $1.88-4.09^{\mathrm{a}}$ & $14.63 \pm 0.56 \times 2.74 \pm 0.11$ & $43.81 \pm 1.60 \times 2.99 \pm 0.09$ \\
\hline JB-12 & $7.89-24.35^{\mathrm{a}}$ & $1.25-4.68^{\mathrm{a}}$ & $32.03-80.28^{a}$ & $2.27-4.14^{\mathrm{a}}$ & $14.75 \pm 0.55 \times 2.71 \pm 0.12$ & $44.32 \pm 1.39 \times 3.19 \pm 0.07$ \\
\hline JB-25 & $7.76-24.03^{\mathrm{a}}$ & $1.68-3.97^{\mathrm{a}}$ & $31.74-80.19^{a}$ & $2.11-4.26^{\mathrm{a}}$ & $14.38 \pm 0.56 \times 2.67 \pm 0.08$ & $44.04 \pm 1.31 \times 3.02 \pm 0.08$ \\
\hline $\mathrm{JB}-27$ & $7.46-23.86^{a}$ & $1.43-4.09^{\mathrm{a}}$ & $31.58-79.93^{\mathrm{a}}$ & $2.05-4.21^{\mathrm{a}}$ & $14.46 \pm 0.58 \times 2.57 \pm 0.10$ & $44.56 \pm 1.62 \times 3.21 \pm 0.09$ \\
\hline
\end{tabular}

${ }^{a}$ Numbers indicate minimum and maximum lengths and widths, respectively, of 50 conidia recorded from each fungal isolate. Significance at $p=0.05$ level. ${ }^{\mathrm{b}} \mathrm{SD}$ means standard deviation. Values within the same column followed by the same letters mean that they are not significantly different based on variance with least significant difference test at $p=0.05$.

\subsection{Molecular Identification and Phylogenetic Analysis}

For further molecular verification, the TEF1 and RPB2 gene sequences of ten representative isolates were amplified and sequenced. All of the obtained sequences were submitted to the NCBI database under the accession numbers listed in Table 2. After analyzing with BLASTn against the NCBI (http:/ / www.ncbi.nlm.nih.gov, accessed on 22 June 2021) and FUSARIUM ID (http:/ / isolate.fusariumdb.org/guide.php, accessed on 22 June 2021) databases, these obtained TEF1 sequences were $99.23 \%$ to $99.54 \%$ identical to sequences of $F$. andiyazi strains and had $98.34 \%$ to $98.64 \%$ identity with $F$. andiyazi strains, such as FD_01386_EF-1a, in Fusarium ID. For RPB2, these isolates also showed 99.05\% to $99.37 \%$ identity with $F$. andiyazi strains in GenBank. The ten representative isolates and a total of 17 other Fusarium isolates were selected for phylogenetic analysis using the concatenated TEF1 and RPB2 gene sequences (Figure 2). Phylogenetic tree analysis revealed that our ten representative isolates were clustered with the F. andiyazi clade, including F. andiyazi strains NRRL 31727, CBS 119856 and CBS 134430 based on the neighbor-joining (NJ) method, which was consistent with the BLASTn homology search results. 


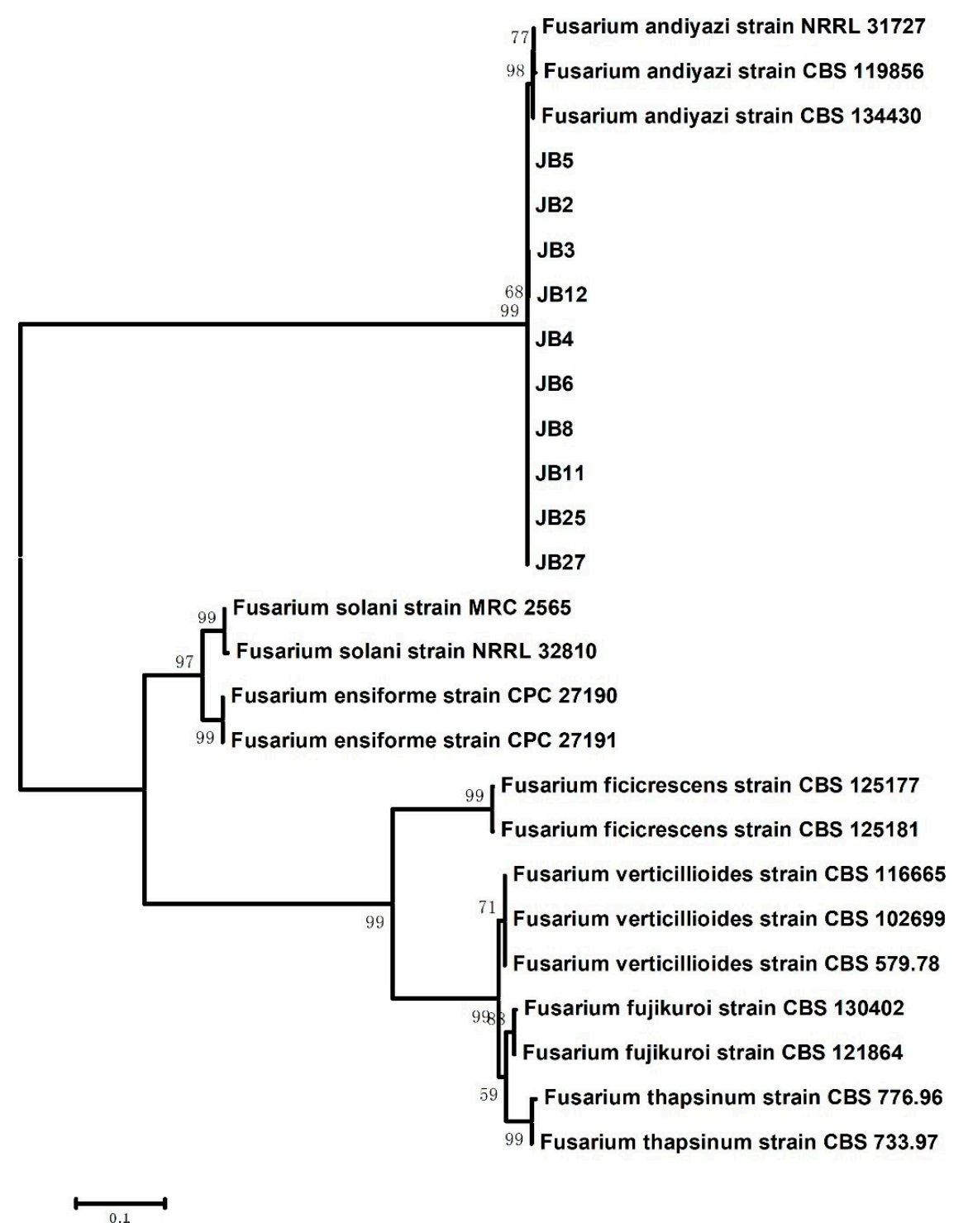

Figure 2. Phylogeny of the representative isolates from Z. latifolia and other Fusarium species. Phylogenetic tree was constructed based on concatenated sequences of translation elongation factor 1- $\alpha$ (TEF1) and the RNA polymerase II subunit beta (RPB2) gene regions. Numbers in the branch were calculated from the bootstrap test of 1000 replicates. Information of the fungal isolates used for phylogenetic tree construction are shown in Table 2.

\subsection{Pathogenicity Assays}

To assess the pathogenicity of the isolated $F$. andiyazi isolates, in vivo inoculation experiments with conidial suspensions were conducted in potted and field Z. latifolia plants (Figure 3). Four representative isolates JB-2, JB-5, JB-6 and JB-27 were randomly selected. Three days after inoculation, symptoms of water soaking were observed on the ear leaf near the sheath. As the disease progressed, the lesions turned visibly dry and brown. In the field inoculation experiment, symptoms displaying as water-soaking and dark brown necrotic lesions surrounded by yellow halos were observed on the inoculated plants after 4 to 5 days of inoculation. No symptoms developed on the control plants. The pathogen fungal isolates were re-isolated from the symptomatic inoculated leaf sheath of Z. latifolia, and their identities were confirmed by morphological and molecular methods as described above, thus fulfilling Koch's postulates. This was the first report of F. andiyazi causing sheath rot in Z. latifolia. 


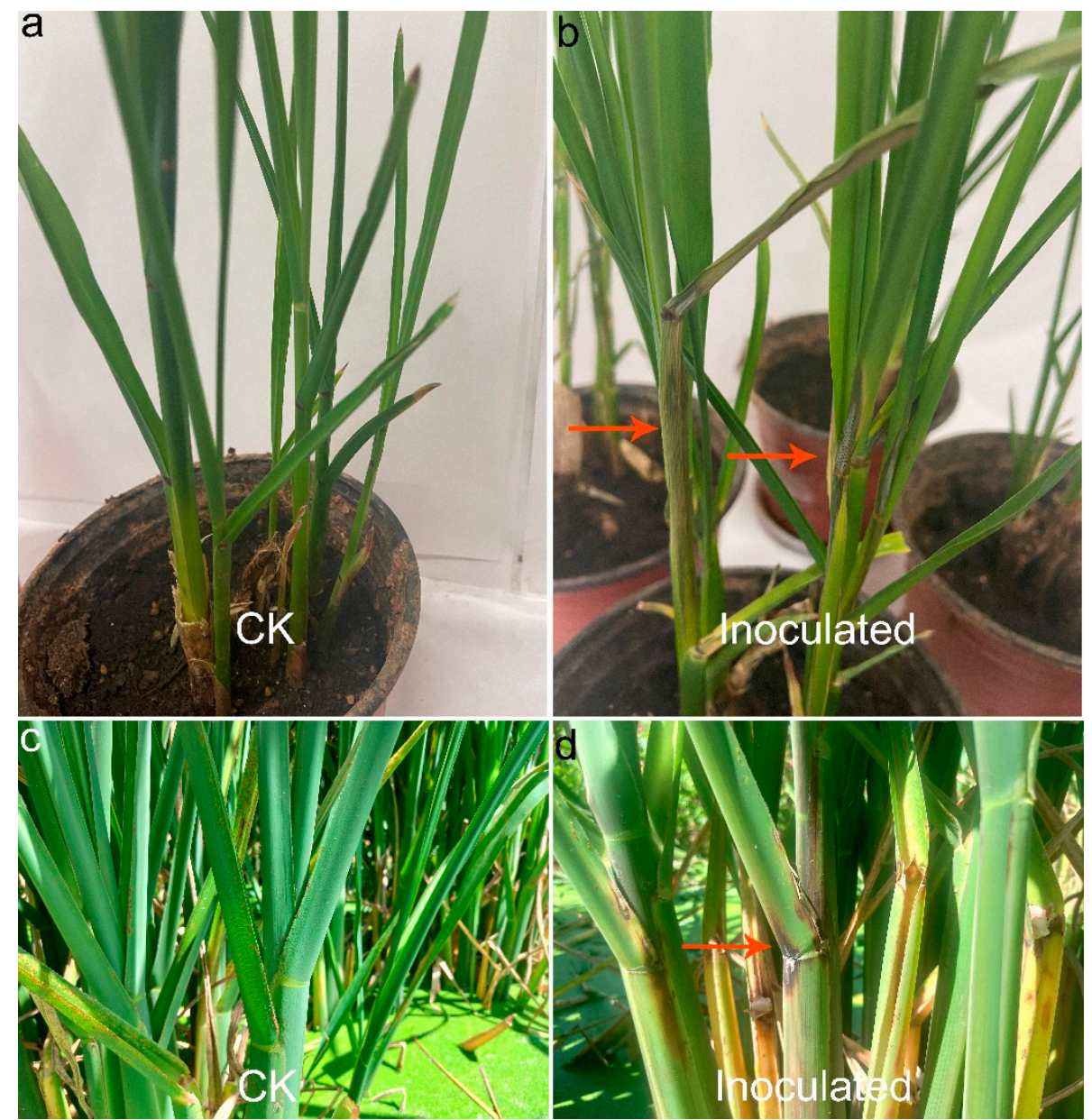

Figure 3. Pathogenicity test on Z. latifolia leaf sheaths. (a,c) Control inoculated plants of potted and field Z. latifolia plants, respectively; (b,d) symptoms of water-soaking and brown necrotic patches were observed on the ear leaf near the sheath of potted and field Z. latifolia plants after three and four days of inoculation, respectively. No obvious symptoms developed on the control plants.

Table 2. GenBank accession numbers of the Fusarium isolates used in this study for phylogenetic analysis.

\begin{tabular}{cccc}
\hline \multirow{2}{*}{ Species } & & \multicolumn{2}{c}{ GenBank Accession Number } \\
\cline { 3 - 4 } & Isolate/Strain & TEF1 & RPB2 \\
\hline Fusarium andiyazi & NRRL 31727 & MN193854.1 & MN193882.1 \\
Fusarium andiyazi & CBS 119856 & MN533989.1 & MN534286.1 \\
Fusarium andiyazi & CBS 134430 & KC954401.1 & LR792614.1 \\
Fusarium andiyazi & JB-2 & MZ396373 & MZ396383 \\
Fusarium andiyazi & JB-3 & MZ396374 & MZ396384 \\
Fusarium andiyazi & JB-4 & MZ396375 & MZ396385 \\
Fusarium andiyazi & JB-5 & MZ396376 & MZ396386 \\
Fusarium andiyazi & JB-6 & MZ396377 & MZ396387 \\
Fusarium andiyazi & JB-8 & MZ396378 & MZ396388 \\
Fusarium andiyazi & JB-11 & MZ396379 & MZ396389 \\
Fusarium andiyazi & JB-12 & MZ396380 & MZ396390 \\
Fusarium andiyazi & JB-25 & MZ396381 & MZ396391 \\
Fusarium andiyazi & JB-27 & MZ396381 & MZ396392 \\
Fusarium solani & MRC 2565 & MH582420.1 & MH582410.1 \\
\hline
\end{tabular}


Table 2. Cont.

\begin{tabular}{cccc}
\hline \multirow{2}{*}{ Species } & & \multicolumn{2}{c}{ GenBank Accession Number } \\
\cline { 3 - 4 } & Isolate/Strain & TEF1 & RPB2 \\
\hline Fusarium solani & NRRL 32810 & DQ247118.1 & EU329624.1 \\
Fusarium ensiforme & CPC 27190 & LT746199.1 & LT746312.1 \\
Fusarium ensiforme & CPC 27191 & LT746200.1 & LT746313.1 \\
Fusarium ficicrescens & CBS 125177 & KP662898.1 & KT154001.1 \\
Fusarium ficicrescens & CBS 125181 & KP662900.1 & KT154003.1 \\
Fusarium fujikuroi & CBS 130402 & KU604446.1 & KU604261.1 \\
Fusarium fujikuroi & CBS 121864 & KU604442.1 & KU604258.1 \\
Fusarium thapsinum & CBS 733.97 & KU604463.1 & KU604299.1 \\
Fusarium thapsinum & CBS 776.96 & KU604462.1 & KU604294.1 \\
Fusarium verticillioides & CBS 102699 & KU604385.1 & KU604218.1 \\
Fusarium verticillioides & CBS 579.78 & KU604390.1 & KU604223.1 \\
Fusarium verticillioides & CBS 116665 & KU604388.1 & KU604221.1 \\
\hline
\end{tabular}

\section{Discussion}

In this study, according to cultural and conidial morphology, TEF1- and RPB2-sequencebased phylogenetic analysis and pathogenicity tests, the pathogen fungus was identified as F. andiyazi and confirmed to be the causal agent of sheath rot in Z. latifolia. Therefore, this study provided the first evidence that $F$. andiyazi is responsible for sheath $\operatorname{rot}$ of $Z$. latifolia. The identification of the pathogen will provide important insights for appropriate field management and control of this new disease.

Fusarium andiyazi was first reported in sorghum (Sorghum bicolor L.) in Africa and the United States [19] and was considered one of the most virulent species causing rot and stalk rot on sorghum seedlings [20-22]. Up to date, F. andiyazi has been reported to cause disease on many plants worldwide, such as pokkah boeng on sugarcane [23-25], ear and root rot in maize [26,27], vascular wilts in oriental melons [28], wilting disease in tomatoes [29], Bakanae on rice $[16,18,30,31]$ and seedling wilt and root rot on sugar beets [32]. However, there are no reports of $F$. andiyazi causing disease in Z. latifolia.

In this study, we identified the isolated fungal isolates as $F$. andiyazi based on both morphological characteristics and molecular sequencing. Because the ITS loci are too conserved to resolve species limits of most fusaria, ITS-rDNA sequencing was not sufficient for differentiating closely related Fusarium spp. The TEF1 and RPB2 sequences were proven to be reasonable loci for identification of Fusarium spp. [33]. In our study, the TEF1 and $R P B 2$ sequences of ten representative isolates were sequenced and blasted against the NCBI and FUSARIUM ID databases. Phylogenetic analysis with the combined TEF1 and RPB2 sequences revealed that our isolated isolates were clustered in the $F$. andiyazi clade, which was consistent with morphological observations.

Zizania latifolia is a perennial plant native to Asia and is widely grown in China and other Asian countries as a popular aquatic vegetable [4,34]. In addition, the swollen culm of Z. latifolia, also known as Jiaobai or Gaogua in China, was recorded as traditional Chinese herbal medicine used for heat clearing, detoxifying, quenching thirst, diuresis, etc. [35]. With food and medicinal values, the cultivation area of Z. latifolia has been largely expanded in China, especially south of the Yangtze River. In this study, sheath rot disease occurred with a high incidence, which damaged the sheath plant, leading to serious loss of production. Its occurrence might bring about a threat to Z. latifolia. Thus, further research for effective management strategies should be conducted to reduce the damage caused by this pathogen.

In conclusion, we identified the causal agent of a novel sheath rot of Z. latifolia. Morphological characteristics of the fungal isolates were observed on the artificial culture medium. Gene sequencing of the TEF1 and RPB2 genes was conducted and confirmed the pathogen to be $F$. andiyazi. Pathogenicity of the isolates was tested, and a difference between isolates was shown. The disease was found to be prevalent in Zhejiang Province 
of China. However, further research of the distribution of $F$. andiyazi on other areas, genetic diversity and pathogenicity differentiation of the pathogen are needed.

\section{Materials and Methods}

\subsection{Sample Collection and Isolation}

Z. latifolia plants infected with visible necrosis were collected from different fields in Lishui, Jinhua, Taizhou and Jiaxing of Zhejiang Province, China. Diseased sheaths were characterized by black-brown lesions surrounded by yellow halos. Two diseased leaf sheaths were collected from survey spots and subjected to pathogen isolation. Symptomatic tissues, in approximately $5 \times 5 \mathrm{~mm}$ fragments, were cut from the edge of lesions, surface sterilized with $70 \%$ ethanol for $30 \mathrm{~s}$ and $1 \% \mathrm{NaClO}$ for $1 \mathrm{~min}$, washed with sterile distilled water three times and then placed onto PDA supplemented with $100 \mathrm{mg} / \mathrm{mL}$ of streptomycin. After 2-3 days of incubation at $26^{\circ} \mathrm{C}$ in the dark, emerged hyphal tips were picked and transferred onto fresh PDA and kept at $26^{\circ} \mathrm{C}$. Fungal cultures were further purified by the single-spore isolation technique [36] and stored at $4{ }^{\circ} \mathrm{C}$ in a refrigerator.

\subsection{Morphological and Cultural Characterization}

For morphological examination, mycelial plugs ( $8 \mathrm{~mm}$ diam) of the fungal isolates were taken from actively growing areas of 5-day-old cultures and plated on PDA at $26{ }^{\circ} \mathrm{C}$ for 6 to 7 days. Colony characteristics, including morphology and color, were observed after 7 days of cultivation. Conidial production was induced after the fungal isolates were grown on CLA at $26^{\circ} \mathrm{C}$ for 7 days, which was the most suitable medium for Fusarium identification, as typical macroconidia, microconidia and chlamydospores were consistently produced in this medium [37]. The morphology of the conidia was examined and photographed under an optical microscope (Life Technologies, EVOS ${ }^{\mathrm{TM}}$ XL Core Imaging System), and their length and width were determined by measuring about 50 randomly selected conidia.

\subsection{DNA Extraction, PCR Amplification, and Sequencing}

Genomic DNA of ten representative fungal isolates was extracted using the CTAB method as described previously [38]. Mycelium was harvested from the colony surface by a sterile medicine spoon. The TEF1 and RPB2 genes were amplified using the primer pairs EF-1/EF-2 (5'-ATGGGTAAGGARGACAAGAC-3' $/ 5^{\prime}$-GGARGTACCAGTSATCAT G-3') and 7cf/11ar (5'-CCCATRGCTTGYTTRCCCAT-3' / $5^{\prime}$-GCRTGGATCTTRTCRTCSA CC-3') [39,40]. Polymerase chain reaction (PCR) amplification was conducted in $50 \mu \mathrm{L}$ volume reaction system containing $25 \mu \mathrm{L}$ of $2 \times$ PCR Master Mix (Vazyme, Nanjing, China), $2 \mu \mathrm{L}$ of each primer $(10 \mu \mathrm{M}), 2 \mu \mathrm{L}$ of genomic DNA template and $19 \mu \mathrm{L}$ of sterile distilled water. PCR was performed with the thermal cycling parameters of $95^{\circ} \mathrm{C}$ for $3 \mathrm{~min}$, followed by 34 cycles of denaturation at $95^{\circ} \mathrm{C}$ for $30 \mathrm{~s}$, annealing at $54-57^{\circ} \mathrm{C}$ for $30 \mathrm{~s}$, extension at $72{ }^{\circ} \mathrm{C}$ for $1 \mathrm{~min}$ and final extension at $72{ }^{\circ} \mathrm{C}$ for $8 \mathrm{~min}$. The PCR products were visualized by running with $1.0 \%$ agarose gel and staining with GoldView ${ }^{\mathrm{TM}}$. The PCR products were sequenced using the dideoxy termination method in Shanghai Sangon Company in China.

\subsection{Phylogenetic Analysis}

All the generated sequences were blasted against the NCBI database and the FUSARIUM ID database for homology searching. Sequences of the top matches and other ex-type isolates of Fusarium species were selected and downloaded from the database for phylogenetic analyses. Sequences were aligned with ClustalX [41], and phylogenetic analysis was performed using the MEGA6 software package [42]. A concatenated phylogenetic tree based on the TEF and RPB1 sequences was constructed using the NJ approach, with the bootstrap values calculated by 1000 replications.

\subsection{Pathogenicity Tests}

Pathogenicity test was conducted by in vivo inoculation with potted and field Z. latifolia plants with conidial suspensions. Four isolates were selected for pathogenicity assays 
that were cultured on PD liquid medium at $26{ }^{\circ} \mathrm{C}$ for 4 days in a shaker incubator $\left(26{ }^{\circ} \mathrm{C}\right.$, $180 \mathrm{rpm} / \mathrm{min})$. Conidial suspensions were harvested by filtering with four layers of a sterile gauze and then adjusted to a final concentration of $1 \times 10^{5}$ spores $/ \mathrm{mL}$ by a hemocytometer. Z. latifolia plants were transplanted in pots that were placed in a greenhouse for one month, and field plot contained 20 lines and 10 plants per line. For greenhouse inoculation, a $1 \mathrm{~mL}$ aliquot of conidial suspensions for the four fungal isolates was injected into the ear leaf near to sheath in a total of fifteen Z. latifolia seedlings planted in three pots, while sterile water was inoculated to fifteen control plants with the same procedure. All the inoculated plants were coated with plastic bags and maintained in a humid growth chamber at $26{ }^{\circ} \mathrm{C}$ under a 16/8 h light/dark cycle. The progression of symptoms was observed daily until necrotic lesions formed. For the field inoculation experiment, a $2 \mathrm{~mL}$ aliquot of the conidial suspensions was injected into the ear leaf as described above. The control plants were inoculated with sterile water. All the inoculated sites were covered with sterile cotton wet with sterile water to maintain moisture. After five to seven days, disease symptoms were assessed. The fungal isolates were considered pathogenic if brown or black necrotic lesions occurred in the inoculated sites. Fungal isolates were re-isolated from the symptomatic inoculated sheaths and re-identified with morphological and molecular characteristics to confirm Koch's postulates.

\subsection{Data Analysis}

Statistical analyses were conducted using Statistical Package for Social Sciences (SPSS) (version 22.0 for Windows). Analysis of variance (ANOVA) in the conidial length and width were performed. Means were compared by the least significant difference test at a significance level of $p=0.05$.

Author Contributions: Conceptualization, J.-Z.Z.; methodology, X.-G.L.; validation, L.-L.W.; formal analysis, J.-Z.Z. and L.-L.W.; investigation, Y.-M.M. and J.-Z.Z.; writing-original draft preparation, Y.-M.M. and J.-Z.Z.; writing-review and editing, J.Z. and X.-G.L.; funding acquisition, J.-Z.Z. All authors have read and agreed to the published version of the manuscript.

Funding: This research was supported by the Key Foundation of Hunan Educational Committee (Grant No. 20A257).

Institutional Review Board Statement: Not applicable.

Informed Consent Statement: Not applicable.

Data Availability Statement: All sequence data are available in NCBI GenBank following the accession numbers in the manuscript.

Conflicts of Interest: The authors declare no conflict of interest.

\section{References}

1. Xu, X.; Walters, C.; Antolin, M.F.; Alexander, M.L.; Lutz, S.; Ge, S.; Wen, J. Phylogeny and biogeography of the eastern Asian-North American disjunct wild-rice genus (Zizania L., Poaceae). Mol. Phylogenet. Evol. 2010, 55, 1008-1017. [CrossRef]

2. Zhang, J.-Z.; Chu, F.-Q.; Guo, D.-P.; Hyde, K.D.; Xie, G.-L. Cytology and ultrastructure of interactions between Ustilago esculenta and Zizania latifolia. Mycol. Prog. 2012, 11, 499-508. [CrossRef]

3. Wang, M.; Zhu, P.; Zhao, S.; Nie, C.; Wang, N.; Du, X.; Zhou, Y. Characterization, antioxidant activity and immunomodulatory activity of polysaccharides from the swollen culms of Zizania latifolia. Int. J. Biol. Macromol. 2017, 95, 809-817. [CrossRef] [PubMed]

4. Guo, H.B.; Li, S.M.; Peng, J.; Ke, W.D. Zizania latifolia Turcz. cultivated in China. Genet. Resour. Crop. Evol. 2007, 54, 1211-1217. [CrossRef]

5. Xiao, Z.-L.; Hyde, K.D.; Zhang, J.-Z. Synonymy of two species of Bipolaris from aquatic crops of Poaceae. Mycotaxon 2015, 130, 131-143. [CrossRef]

6. Cho, W.D.; Shin, H.D. List of Plant Diseases in Korea; The Korean Society of Plant Pathology: Suwon, Korea, 2004; pp. 168-169.

7. Huang, J.-H.; Chen, C.-Y.; Lin, Y.-S.; Ann, P.-J.; Huang, H.-C.; Chung, W.-H. Six new species of Pythiogeton in Taiwan, with an account of the molecular phylogeny of this genus. Mycoscience 2013, 54, 130-147. [CrossRef]

8. Ann, P.J.; Huang, J.H.; Wang, I.T.; Ko, W.H. Pythiogeton zizaniae, a new species causing basal stalk rot of water bamboo in Taiwan. Mycologia 2006, 98, 116-120. [CrossRef] 
9. Li, P.P.; Cao, Z.Y.; Wang, K.; Zhai, H.; Jia, H.; Liu, N.; Li, S.H.; Hao, Z.M.; Gu, S.Q.; Dong, J.G. First report of Fusarium equiseti causing a sheath rot of corn in China. Plant Dis. 2014, 98, 998. [CrossRef]

10. Lan, H.; Xiude, X.; Yu, J. Study on biological characteristics of corn sheath rot causal agent. J. Maize Sci. 2008, 16, 131-134.

11. Yang, Q.; Balint-Kurti, P.; Xu, M. Quantitative Disease Resistance: Dissection and Adoption in Maize. Mol. Plant 2017, 10, 402-413. [CrossRef]

12. Wang, W.; Wang, B.; Sun, X.; Qi, X.; Zhao, C.; Chang, X.; Khaskheli, M.I.; Gong, G. Symptoms and pathogens diversity of Corn Fusarium sheath rot in Sichuan Province, China. Sci. Rep. 2021, 11, 2835. [CrossRef]

13. Leslie, J.F.; Summerell, B.A. (Eds.) The Fusarium Laboratory Manual; Blackwell: Ames, IO, USA, 2006.

14. Geiser, D.M.; Jiménez-Gasco, M.D.M.; Kang, S.; Makalowska, I.; Veeraraghavan, N.; Ward, T.J.; Zhang, N.; Kuldau, G.A.; O'Donnell, K. FUSARIUM-ID v. 1.0: A DNA Sequence Database for Identifying Fusarium. Eur. J. Plant Pathol. 2004, 110, 473-479. [CrossRef]

15. Madania, A.; Altawil, M.; Naffaa, W.; Volker, P.H.; Hawat, M. Morphological and Molecular Characterization of Fusarium Isolated from Maize in Syria. J. Phytopathol. 2013, 161, 452-458. [CrossRef]

16. Prà, M.D.; Tonti, S.; Pancaldi, D.; Nipoti, P.; Alberti, I. First Report of Fusarium andiyazi Associated with Rice Bakanae in Italy. Plant Dis. 2010, 94, 1070. [CrossRef]

17. Qiu, J.; Lu, Y.; He, D.; Lee, Y.W.; Ji, F.; Xu, J.; Shi, J. Fusarium fujikuroi species complex associated with rice, maize, and soybean from Jiangsu Province, China: Phylogenetic, pathogenic, and toxigenic analysis. Plant Dis. 2020, 104, 2193-2201. [CrossRef] [PubMed]

18. Wulff, E.G.; Sørensen, J.L.; Lübeck, M.; Nielsen, K.F.; Thrane, U.; Torp, J. Fusariumspp. associated with rice Bakanae: Ecology, genetic diversity, pathogenicity and toxigenicity. Environ. Microbiol. 2010, 12, 649-657. [CrossRef]

19. Marasas, W.F.O.; Rheeder, J.P.; Lamprecht, S.C.; Zeller, K.A.; Leslie, J.F. Fusarium andiyazi sp. nov., a new species from sorghum. Mycologia 2001, 93, 1203-1210. [CrossRef]

20. Leslie, J.F.; Zeller, K.A.; Lamprecht, S.C.; Rheeder, J.P.; Marasas, W.F.O. Toxicity, Pathogenicity, and Genetic Differentiation of Five Species of Fusarium from Sorghum and Millet. Phytopathology 2005, 95, 275-283. [CrossRef]

21. Leslie, J.F.; Summerell, B.A. The Fusarium Laboratory Manual; John Wiley \& Sons: Hoboken, NJ, USA, 2008.

22. Kelly, L.A.; Tan, Y.P.; Ryley, M.J.; Aitken, E. Fusarium species associated with stalk rot and head blight of grain sorghum in Queensland and New South Wales, Australia. Plant Pathol. 2017, 66, 1413-1423. [CrossRef]

23. Govender, P.; McFarlane, S.A.; Rutherford, R.S. Fusarium species causing pokkah boeng and their effect on Eldana saccharina walker (lepidoptera pyralidae). Proc. S. Afr. Sug. Technol. Assess. 2010, 83, 267-270.

24. Costa, M.M.; Melo, M.P.; Guimarães, E.A.; Veiga, C.M.O.; Carmo Sandin, F.; Moreira, G.M.; Costa, S.S.; Pfenning, L.H. Identification and pathogenicity of Fusarium species associated with pokkah boeng of sugarcane in Brazil. Plant. Pathol. 2019, 68, 1350-1360. [CrossRef]

25. Bao, Y.; Huang, Z.; Li, T.; Yao, Z.; Powell, C.A.; Zhang, M. First Report of Fusarium andiyazi Causing Sugarcane Pokkah Boeng Disease in China. Plant Dis. 2020, 104, 286. [CrossRef]

26. Zhang, H.; Luo, W.; Pan, Y.; Xu, J.S.; Chen, W.Q.; Feng, J. First Report of Fusarium Ear Rot of Maize Caused by Fusarium andiyazi in China. Plant Dis. 2014, 98, 1428. [CrossRef]

27. Venturini, G.; Toffolatti, S.L.; Quaglino, F.; Casati, P. First Report of Fusarium andiyazi Causing Ear Rot on Maize in Italy. Plant Dis. 2017, 101, 839. [CrossRef]

28. Seo, Y.; Kim, Y.H. Potential Reasons for Prevalence of Fusarium Wilt in Oriental Melon in Korea. Plant Pathol. J. 2017, 33, $249-263$. [CrossRef] [PubMed]

29. Isaac, M.R.; Leyva-Mir, S.G.; Sahagun-Castellanos, J.; Camara-Correia, K.; Tovar-Pedraza, J.M.; Rodriguez-Perez, J.E. Occurrence, identification, and pathogenicity of Fusarium spp. associated with tomato wilt in Mexico. Not. Bot. Horti. Agrobo. 2018, 46, 484-493. [CrossRef]

30. Hsuan, H.M.; Salleh, B.; Zakaria, L. Molecular Identification of Fusarium Species in Gibberella fujikuroi Species Complex from Rice, Sugarcane and Maize from Peninsular Malaysia. Int. J. Mol. Sci. 2011, 12, 6722-6732. [CrossRef] [PubMed]

31. Choi, H.W.; Hong, S.K.; Lee, Y.K.; Kim, W.G.; Chun, S. Taxonomy of Fusarium fujikuroi species complex associated with ba-kanae on rice in Korea. Australas. Plant. Path. 2018, 47, 23-34. [CrossRef]

32. Taha, E.M. Morphological, phylogenetic, and pathogenic analyses of Fusarium andiyazi associated with sugar beet root diseases. Arch. Phytopathol. Plant Prot. 2020, 54, 319-333. [CrossRef]

33. O'Donnell, K.; Ward, T.J.; Robert, V.A.R.G.; Crous, P.W.; Geiser, D.M.; Kang, S. DNA sequence-based identification of Fusarium: Current status and future directions. Phytoparasitica 2015, 43, 583-595. [CrossRef]

34. Guo, L.; Qiu, J.; Han, Z.; Ye, Z.; Chen, C.; Liu, C.; Xin, X.; Ye, C.-Y.; Wang, Y.-Y.; Xie, H.; et al. A host plant genome (Zizania latifolia) after a century-long endophyte infection. Plant J. 2015, 83, 600-609. [CrossRef]

35. Wang, M.C.; Zhao, S.W.; Zhu, P.L.; Nie, C.; Ma, S.P.; Wang, N.F.; Du, X.F.; Zhou, Y.B. Purification, characterization and immunomodulatory activity of water extractable polysaccharides from the swollen culms of Zizania latifolia. Int. J. Biol. Macro Mol. 2018, 107, 882-890. [CrossRef] [PubMed]

36. Pathak, V.N. Essentials of Plant Pathology; Prakesh Publishers: Jaipur, India, 1972; p. 448.

37. Burgess, L.W.; Summerell, B.A.; Nelson, P.E. An Evaluation of Several Media for Use in Identification of Some Fusarium Species. Australas. Plant Pathol. 1991, 20, 86-88. [CrossRef] 
38. White, T.J.; Bruns, T.; Lee, S. Amplification and direct seqencing of fungal ribosomal RNA genes for phylogenetics. PCR Protoc. 1990, 18, 315-322.

39. O'Donnell, K.; Cigelnik, E.; Nirenberg, H.I. Molecular Systematics and Phylogeography of the Gibberella fujikuroi Species Complex. Mycologia 1998, 90, 465. [CrossRef]

40. O’Donnell, K.; Sutton, D.A.; Rinaldi, M.G.; Sarver, B.A.J.; Balajee, S.A.; Schroers, H.-J.; Summerbell, R.C.; Robert, V.A.R.G.; Crous, P.W.; Zhang, N.; et al. Internet-Accessible DNA Sequence Database for Identifying Fusaria from Human and Animal Infections. J. Clin. Microbiol. 2010, 48, 3708-3718. [CrossRef]

41. Thompson, J.D.; Gibson, T.J.; Plewniak, F. The CLUSTAL_X windows interface: Flexible strategies for multiple sequence align-ment aided by quality analysis tools. Nucleic. Acids. Res. 1997, 25, 4876-4882. [CrossRef]

42. Tamura, K.; Stecher, G.; Peterson, D. MEGA6: Molecular evolutionary genetics analysis version 6.0. Mol. Biol. Evol. 2013, 30, 2725-2729. [CrossRef] 